\title{
The DAIR (debridement, antibiotics and implant retention) procedure for infected total knee replacement - a literature review
}

\author{
Sultan Naseer Qasim ${ }^{1, *}$, Andrew Swann ${ }^{2}$, and Robert Ashford ${ }^{3}$ \\ ${ }^{1}$ Orthopaedic Resident, Leicester Orthopaedics, University Hospitals of Leicester, Leicester LE1 5WW, UK \\ 2 Consultant Microbiologist, University Hospitals of Leicester, Leicester LE1 5WW, UK \\ 3 Consultant Orthopaedic and Sarcoma Surgeon, Leicester Orthopaedics, University Hospitals of Leicester, Leicester LE1 5WW, UK
}

Received 26 August 2015, Accepted 8 November 2016, Published online 11 January 2017

\begin{abstract}
Prosthetic joint infection (PJI) is a devastating complication in total knee arthroplasty (TKA) and third most common cause of revision of TKA with significant morbidity and surgical challenges. Treatment options include non-operative measures with long term antibiotic suppression, debridement and implant retention (DAIR), one- or two-stage revision arthroplasty, arthrodesis and amputation. Implant retention without infection is ideal and DAIR has been reported to have variable success rates depending on patient factors, duration of infection, infecting micro-organisms, choice of procedure, single or multiple debridement procedures, arthroscopic or open, antibiotic choice and duration of antibiotic use. We present a thorough literature review of DAIR for infected TKA. The important factors contributing to failure are presence of sinus, immunocompromised patient, delay between onset of infection and debridement procedure, Staphylococcal infection in particular Meticillin Resistant Staphylococcal aureus, multiple debridement procedures, retention of exchangeable components and short antibiotic duration. In conclusion DAIR can be successful procedure to eradicate infection in TKA in selective patients with factors contributing to failure taken into account.
\end{abstract}

Key words: Debridement and implant retention, DAIR, Infected total knee arthroplasty, Prosthetic joint infection.

\section{Introduction}

Knee replacement is an effective procedure for end-stage knee arthritis. According to the National Joint Registry report of 2013 [1], 22\% of revision procedures were performed for infection and according to the National Joint Registry report of 2014 [1] infection is the third most common cause of revision after aseptic loosening and pain with 1.06 revision per 1000 patient-years. It is, however, one of the most dreaded complications for orthopaedic surgeons because of significant morbidity and because of the surgical challenges it poses.

The treatment options for an infected total knee arthroplasty (TKA) are usually surgical as antibiotics in isolation are not an appropriate treatment unless there is significant co-morbidity providing a relative contra-indication for surgery [2]. The surgical options include washout, debridement, antibiotics and implant retention (DAIR), one- or two-stage revision total knee arthroplasty, arthrodesis and amputation. Prosthetic joint infection (PJI) surgery also poses significant

\footnotetext{
*Corresponding author: drsnqasim@gmail.com
}

cost implications [3] as it could require multiple procedures, prolonged antibiotics, lengthy hospital stays and more expensive implants for revision surgery.

Two-stage revision arthroplasty is considered the gold standard for an infected prosthesis. However, it poses significant challenges to both patient and surgeon. Two operations with a substantial period of reduced mobility and significant anaesthetic and surgical risks are major concerns for the patient. There are significant challenges for the surgeon in removing a well-fixed prosthesis with removal of bone cement. This poses risk of significant damage to the remaining bone stock, making reconstruction difficult with increased risk of perioperative and postoperative complications and potentially compromising the soft tissue envelope.

Implant retention without infection is the ideal end result of treatment for an infected total knee arthroplasty. Some surgeons prefer to perform debridement of the knee, particularly in the case of acute infection, to reduce the infective organism load and supplement debridement with systemic antibiotics. Their aim is to retain the implant and to avoid further more invasive/complex surgery. There are no 

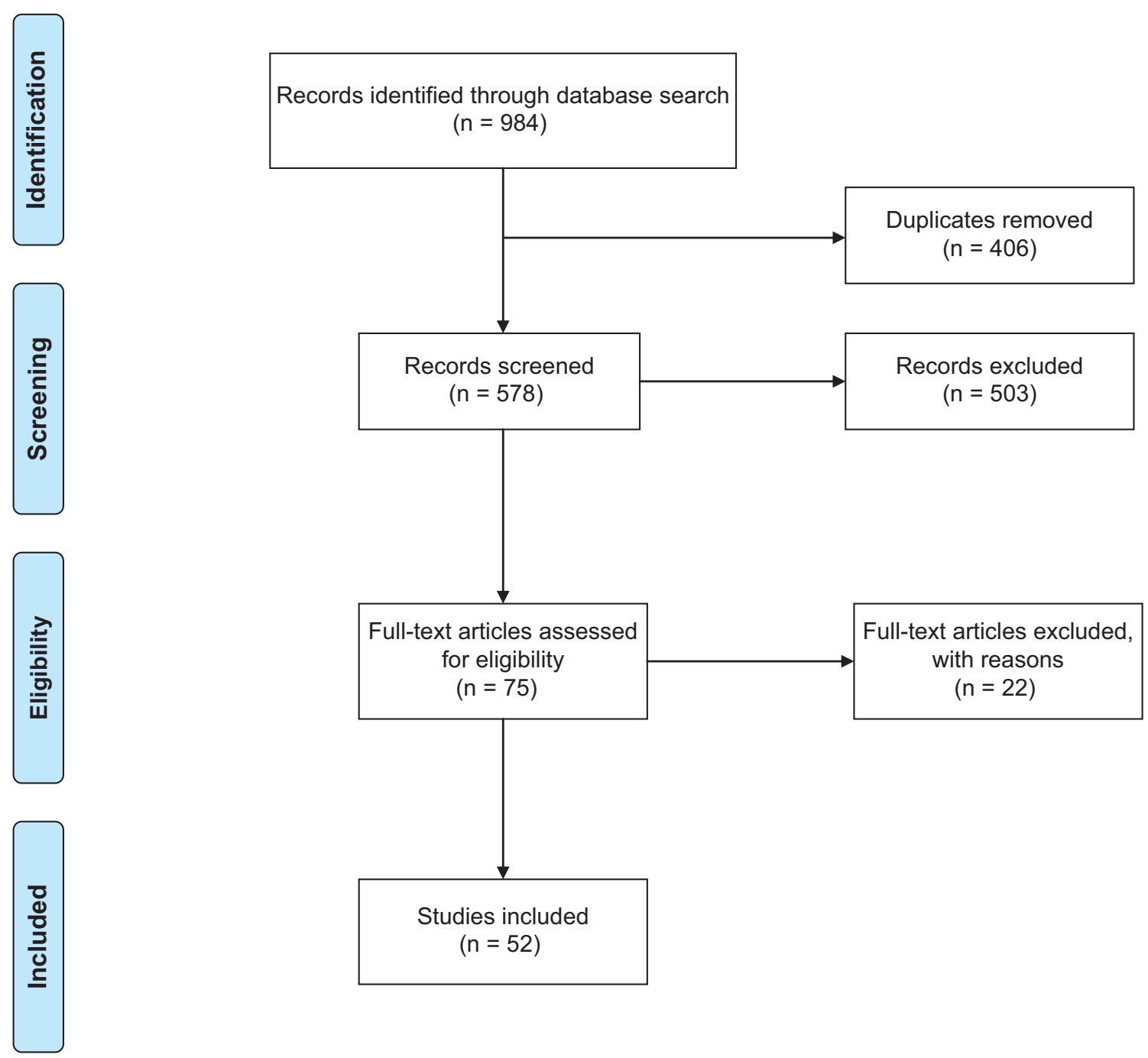

Figure 1. PRISMA flowchart.

randomized controlled or prospective trials. The literature consists of various retrospective series both in Orthopaedic and Microbiology journals with variable opinions over each aspect of DAIR.

We, therefore, present a thorough review of literature for role of the DAIR procedure as a treatment option for infected TKA.

\section{Materials and methods}

MEDLINE was searched using the PubMed and Embase interface to identify relevant studies pertaining to debridement and implant retention in infected knee arthroplasty up to June 2015. Keyword searches used were "prosthetic joint infection", "infected knee arthroplasty", "infected knee replacement", "debridement", "implant retention" and "DAIR". Inclusion criteria included all articles which described implant retention for infected knee arthroplasty published in the English language or with abstracts in English.

PRISMA guidelines were used as shown in Figure 1.
Data extracted from the studies included patient factors, duration of symptoms, micro-organisms identified, procedure performed - open/arthroscopic and single/multiple debridement, duration of antibiotic and long-term results.

The principal outcome measure was failure of the procedure and was defined as failure to eradicate infection and need for further procedure that included revision, arthrodesis or amputation. Some of the key studies are shown in Table 1.

\section{Results and discussions}

\section{Patient factors}

A patient's innate immunity is a well-established factor for infection control after prosthetic joint infection (PJ). The risk factors for failure after DAIR are no different to any other surgical procedure. The condition of local soft tissues is of particular significance [4]. Persistence of a sinus has been shown to be a risk factor for failure [5-7] and a contraindication to DAIR. Furthermore, DAIR relies on patient immunity 
Table 1. Key studies.

\begin{tabular}{|c|c|c|c|}
\hline $\begin{array}{l}\text { Study (year of } \\
\text { publication) }\end{array}$ & $\begin{array}{c}\text { Number of } \\
\text { patients }\end{array}$ & Success rate & Comments \\
\hline Segawa et al. [4] (1999) & 81 & $85 \%$ & $\begin{array}{l}\text { Major factor associated with treatment failure was compromised immune status. } \\
\text { Bone loss and necrosis of soft tissues also contributed. }\end{array}$ \\
\hline $\begin{array}{l}\text { Marculescu et al. [5] } \\
\text { (2006) }\end{array}$ & 99 & $60 \%$ & Sinus tract and duration of symptoms $>8$ days independent risk factors for failure. \\
\hline Hsieh et al. [30] (2009) & 346 & $\begin{array}{l}\text { GN PJI } 27 \% \\
\text { GP PJI } 47 \%\end{array}$ & $\begin{array}{l}\text { Debridement alone has a high failure rate and should not be attempted when the } \\
\text { duration of symptoms is long. }\end{array}$ \\
\hline $\begin{array}{l}\text { Deirmengian et al. [23] } \\
\quad(2003)\end{array}$ & 31 & $35 \%$ & $\begin{array}{l}\text { Success rate of DAIR depends on involved pathogen. Streptococcal or } \\
\text { Staphylococcus epidermidis has better success rate if done within 2-3 days } \\
\text { of symptom onset. }\end{array}$ \\
\hline $\begin{array}{l}\text { Triantafyllopoulos et al. } \\
\text { [29] (2014) }\end{array}$ & 78 & $55 \%$ & MRSA success rate of $45.1 \%$. \\
\hline $\begin{array}{l}\text { Zürcher-Pfund et al. } \\
\text { [32] (2013) }\end{array}$ & 21 & $33 \%$ & $0 / 3$ for MRSA. \\
\hline $\begin{array}{l}\text { Geurts et al. [13] } \\
\quad(2013)\end{array}$ & 20 & $85 \%$ & Rate of failure associated with number of debridement procedures. \\
\hline $\begin{array}{l}\text { Gardner et al. [12] } \\
\quad(2011)\end{array}$ & 44 & $43 \%$ & Staph aureus infection with greater failure. \\
\hline Choi et al. [34] (2011) & 32 & $31 \%$ & Staphylococcal infection and polyethylene non-exchange major \\
\hline $\begin{array}{l}\text { Koyonos et al. [33] } \\
\quad(2011)\end{array}$ & 138 & $\begin{array}{l}31 \% \text { Acute } \\
44 \% \text { Acute } \\
\text { delayed } \\
28 \% \text { Chronic }\end{array}$ & Staphylococcal infection, most significant indicator of failure. \\
\hline $\begin{array}{l}\text { Azzam et al. [22] } \\
\text { (2010) }\end{array}$ & 104 & $44 \%$ & DAIR has a low success rate. Effective for low virulence organisms. \\
\hline $\begin{array}{l}\text { Vilchez et al. [21] } \\
\text { (2011) }\end{array}$ & 65 & $\begin{array}{l}\text { Haematogenous } \\
\quad \text { PJI }-45 \% \\
\text { Early PJI }-75 \%\end{array}$ & $\begin{array}{l}\text { Haematogenous PJI due to } S \text {. aureus, using debridement with implant retention, had a } \\
\text { worse outcome than early post-surgical infections. }\end{array}$ \\
\hline $\begin{array}{l}\text { Bradbury et al. [26] } \\
\text { (2009) }\end{array}$ & 19 & $18 \%$ & $\begin{array}{l}\text { The total success rate of open irrigation and debridement with component retention } \\
\text { (ODCR) in acute periprosthetic MRSA knee infection was } 18 \% \text {. }\end{array}$ \\
\hline $\begin{array}{l}\text { Chung et al. [45] } \\
\text { (2014) }\end{array}$ & 16 & $100 \%$ & $62.5 \%$ Arthroscopy alone; the rest needed further open debridement. \\
\hline Liu et al. [43] (2013) & 17 & $88 \%$ & $\begin{array}{l}\text { Arthroscopic debridement with continuous irrigation and suction effective in } \\
\text { prosthesis retention. }\end{array}$ \\
\hline Mont et al. [44] (1997) & 24 & $80 \%$ & DAIR effective for early PJI. \\
\hline Trebse et al. [7] (2005) & 24 & $86 \%$ & DAIR effective for treating early PJI. \\
\hline Pavoni et al. [2] (2004) & 34 & $91 \%$ & Treatment with long-term antibiotics alone in PJI can yield good results. \\
\hline $\begin{array}{l}\text { Sherrell et al. [52] } \\
\quad(2011)\end{array}$ & 83 & $66 \%$ & $\begin{array}{l}\text { High failure rate after two-stage revision is worse in patients previously treated with } \\
\text { DAIR. }\end{array}$ \\
\hline $\begin{array}{l}\text { Lora-Tamayo et al. [28] } \\
\text { (2013) }\end{array}$ & 345 & $55 \%$ & $\begin{array}{l}\text { The use of rifampicin may have contributed to homogenizing MSSA and MRSA } \\
\text { prognoses, although the specific rifampicin combinations may have had different } \\
\text { efficacies. }\end{array}$ \\
\hline Puhto et al. [49] (2012) & 86 & $89.5 \%$ & Shorter course of antibiotics is as effective as longer antibiotics course. \\
\hline Cobo et al. [25] (2011) & 117 & $57.3 \%$ & DAIR recommended in early PJI \\
\hline Byren et al. [48] (2009) & 112 & $72 \%$ & DAIR effective in PJI \\
\hline
\end{tabular}

to combat infection $[4,6,8]$; hence, it is not a suitable procedure in the immunocompromised individual. It may be appropriate in individuals with significant morbidity who are unsuitable for alternative surgical options with higher morbidity.

\section{Duration of symptoms}

Various definitions of PJI have been described. The American Academy of Orthopaedic Surgeons working party proposed diagnostic criteria for PJI [9] to aid decision making. Cui et al. [10] classified infections into four types as shown in Table 2.
Success rates of $28 \%-62 \%$ have been shown with DAIR for late chronic or established Prosthetic Joint Infection as compared to $31 \%-100 \%$ with acute infections. Furthermore, acute postoperative infection has shown better results as compared to haematogenous spread $[6,11-21]$.

\section{Microbiology}

Many organisms have been isolated in infected total knee arthroplasty. Common pathogens include meticillin-sensitive and meticillin-resistant Staphylococcus aureus (MSSA and MRSA), coagulase-negative staphylococci, streptococci and 
Table 2. Types of prosthetic joint infection according to Cui et al. [10].

\begin{tabular}{ll}
\hline Acute postoperative & $\leq 4$ weeks postoperative \\
Late chronic & Indolent infection $>4$ weeks postoperative \\
Acute haematogenous & Acute onset at the site of a previously well-functioning prosthetic joint \\
Positive intra-operative culture & Clinically unapparent infection with two or more positive intra-operative cultures \\
\hline
\end{tabular}

Gram-negative bacteria. Staphylococcus aureus is generally pyogenic and often accounts for acute postoperative infections. Coagulase-negative staphylococci are often associated with late chronic or clinically unapparent infections, typically as a result of biofilm production.

Multiple studies have shown Staphylococcus aureus infection to be an independent risk factor for failure to eradicate infection $[12,18,22-25]$. MRSA, in particular, has shown high failure rates with DAIR [26-29]. Gramnegative organisms have shown a variable outcome in failure rates as compared to Gram-positive organisms [21, 30, 31]. The decision to retain implant should depend on pathogen e.g. not to retain in cases of MRSA infection as echoed by Zürcher-Pfundet et al. [32]. DAIR has shown to be particularly effective in patients who are not immunocompromised and with PJIs caused by a low virulence organism e.g. coagulasenegative staphylococci $[12,23,33]$.

\section{Procedure}

The principles of debridement for infected arthroplasty are to withhold antibiotics and to aspirate the joint to identify organism prior to surgery. The surgical procedure includes removal of skin margins, excision of any sinuses, radical synovectomy and exchange of removable implants (polyethylene insert in case of total knee arthroplasty). In the case of a modular total knee replacement, removal of the polyethylene tibial insert is very important in order to gain access to posterior aspect of the joint. Choi et al. [34] showed that not exchanging the polyethylene insert was an independent risk factor for failure. Based on this, patients with an allpolyethylene tibial component might not be good candidates for implant retention.

The joint must have a thorough lavage. Recently there has been increased interest in using chlorhexidine gluconate $0.05 \%$. Schwechter [35] undertook an in vitro research to investigate the replication of adherence of MRSA to orthopaedic implants by creating a biofilm model using titanium discs. They found chlorhexidine gluconate to be most effective in reducing bacterial colony counts and was superior to pulsed saline lavage.

A suction drain should be left in situ until there is minimal output. If drainage persists or if the infection fails to settle then consideration has to be given to a further debridement procedure. Continuous closed irrigation has not proven to be any more effective than standard procedure with primary closure and in situ drain [36].

Martel-Laferrière et al. [37] and others [22, 38, 39] have proposed treatment algorithms but Gardener highlights that no single treatment algorithm is preferable to any other [28].

\section{Arthroscopic versus open}

A DAIR procedure cannot be carried out arthroscopically because this does not allow adequate debridement or exchange of the polyethylene insert. Some authors [40-42] have utilized arthroscopic washout in acute infections. Ilahi et al. [41] report $100 \%$ success in seven patients and Liu et al. [43] report $88 \%$ success rate in 15 patients they treated but others report a much lower success rate [42, 45] when compared to open debridement. We do not advocate this as the procedure of choice.

\section{Single versus multiple}

Most studies would regard the need for a further procedure as failure of the index procedure. Vilchez et al. [39] showed that repeat procedure was an independent predictor of failure. Therefore, repeated DAIR procedures are not recommended and indicate failure and need for alternative procedure [23, 37]. However, Mont et al. [44] performed that repeated DAIR is successful in early infection.

\section{Antibiotic choice}

The choice of antibiotic will depend on a number of factors including susceptibilities of pathogens isolated, route of administration and likely duration of treatment. Regimens for intravenous or highly bioavailable oral antimicrobial treatment of particular pathogens have been recommended [45]. Individual regimens should be chosen following discussion between orthopaedic surgeons and microbiologists or infectious disease specialists.

\section{Antibiotic duration}

This by far is the most controversial issue in the treatment of prosthetic joint infection. The duration varies from no extended regimen [47] to indefinite [2]. Byren et al. [48] treated their patients with systemic antibiotics for an average of 1.5 years and cited antibiotic duration as a major risk factor for failure. Puhto et al. [49] found no difference in the recurrence of infection when antibiotics were used for three or six months post-procedure, thus advocating shorter duration. Laffer et al. [16] showed similar results. Bernard et al. [50] showed that even six weeks of postoperative antibiotics had similar results as compared to long-term use. Moran et al. [51] recommend the use of broad spectrum agent in the early empirical antibiotic regime for PJI. We believe, however, that DAIR may require longer antibiotic use than in revision procedure. Nevertheless, it is agreed that the duration depends on the virulence of the offending pathogen, the need for repeat 
procedures and host factors. In some cases, chronic suppressive antibiotic therapy may be appropriate, especially in those for whom further surgical options are not possible for either medical or surgical reasons.

\section{Long-term results}

Failure of a DAIR procedure will necessitate alternative surgical options with two-stage procedure being the gold standard. Gardner et al. [12], Choi et al. [34] and Sherrell et al. [52], however, showed that a two-stage procedure, in a patient with previous debridement, has an inferior success rate and outcome when compared to a primary procedure. In the study by Choi [34], in 22 failed initial DAIR procedures, staged revision (11 knees), repeated incision and drainage (I\&D) (11 knees), fusion (two knees), amputation (two knees) and resection (one knee) were performed.

\section{Recommendation}

We recommend a DAIR procedure in the acute postoperative period within four weeks of surgery or acute haematogenous infection of TKA within two weeks of onset. The procedure should be open rather than arthroscopic and the polyethylene insert exchanged where possible. Postoperative antibiotics should be given for six weeks and the progress monitored by clinical examination and inflammatory markers. Immunocompromise, MRSA infection, poor condition of local soft tissues and failure of one DAIR procedure should prompt revision arthroplasty.

\section{Conclusion}

Debridement, antibiotics and implant retention (the DAIR) procedure can be a successful treatment option for PJI in TKA. It can effectively eradicate infection, resulting in improved functional outcome and a reduction in the need of more extensive surgery which may be associated with far greater morbidity. Individual factors affecting outcome include patient factors, presence of sinus, duration of infection, virulence of organism, meticulous procedure, exchange of polyethylene insert and duration of appropriate antibiotic use. Failure of a DAIR procedure generally requires more radical procedures such as revision arthroplasty.

\section{Conflict of interest}

Authors SQ, AS, RA certify that they have no financial conflict of interest (e.g. consultancies, stock ownership, equity interest, patent/licensing arrangements, etc.) in connection with this article. The institution of authors SQ, AS, RA (University Hospitals of Leicester NHS Trust) has not received any funding related to this article.

\section{References}

1. National Joint Registry for England, Wales and Northern Ireland (2014) 11th Annual Report, www.njrreports.org.uk.
2. Pavoni GL, Giannella M, Falcone M, Scorzolini L, Liberatore M, Carlesimo B, Venditti M, Serra P (2004) Conservative medical therapy of prosthetic joint infections: retrospective analysis of an 8-year experience. Clin Microbiol Infect, 10(9), 831-837.

3. Merollini KM, Crawford RW, Graves N (2013) Surgical treatment approaches and reimbursement costs of surgical site infections post hip arthroplasty in Australia: a retrospective analysis. BMC Health Serv Res, 11(13), 91.

4. Segawa H, Tsukayama DT, Kyle RF, Becker DA, Gustillo RB (1999) Infection after total knee arthoplasty. A retrospective study of the treatment of eighty-one infections. J Bone Joint Surg Am, 81(10), 1434-1445.

5. Marculescu CE, Berbari EF, Hanssen AD, Steckelberg JM, Harmsen SW, Mandrekar JN, Osmon DR (2006) Outcome of prosthetic joint infections treated with debridement and retention of components. Clin Infect Dis, 42(4), 471-478.

6. Silva M, Tharani R, Schmalzried TP (2002) Results of direct exchange or debridement of the infected total knee arthroplasty. Clin Orthop Relat Res, 404, 125-131.

7. Trebse R, Pisot V, Trampuz A (2005) Treatment of infected retained implants. J Bone Joint Surg Br, 87(2), 249-256.

8. Kuiper JW, Vos SJ, Saouti R, Vergroesen DA, Graat HC, Debets-Ossenkopp YJ, Peters EJ, Nolte PA. 2013. Prosthetic joint-associated infections treated with DAIR (debridement, antibiotics, irrigation, and retention). Acta Orthop, 84(4), 380-386.

9. Valle CD, Parvizi J, Bauer TW, DiCesare PE, Evans RP, Segreti J, Spangehl M, Watters WC III, Keith M, Turkelson CM, Wies JL, Sluka P, Hitchcock K (2010) Diagnosis of periprosthetic joint infections of the hip and knee. Journal of the American Academy of Orthopaedic Surgeons, 18(12), 760-770.

10. Cui Q, Mihalko WM, Shields JS, Ries M, Saleh KJ (2007) Antibiotic-impregnated cement spacers for the treatment of infection associated with total hip or knee arthroplasty. J Bone Joint Surg Am, 89(4), 871-882.

11. Chiu FY, Chen CM (2007) Surgical débridement and parenteral antibiotics in infected revision total knee arthroplasty. Clin Orthop Relat Res, 461, 130-135.

12. Gardner J, Gioe TJ, Tatman P (2011) Can this prosthesis be saved?: implant salvage attempts in infected primary total knee arthroplasty. Clin Orthop Relat Res, 469(4), 970-976.

13. Geurts JA, Janssen DM, Kessels AG, Walenkamp GH. 2013. Good results in postoperative and hematogenous deep infections of 89 stable total hip and knee replacements with retention of prosthesis and local antibiotics. Acta Orthop, 84(6), 509-516.

14. Hanssen AD (2002) Managing the infected knee: as good as it gets. J Arthroplasty, 17(4 Suppl 1), 98-101.

15. Kuiper JW, Willink RT, Moojen DJ, van den Bekerom MP, Colen S (2014) Treatment of acute periprosthetic infections with prosthesis retention: review of current concepts. World J Orthop, 5(5), 667-676.

16. Laffer RR, Graber P, Ochsner PE, Zimmerli W (2006) Outcome of prosthetic knee-associated infection: evaluation of 40 consecutive episodes at a single centre. Clin Microbiol Infect, 12(5), 433-439.

17. Rasul AT Jr, Tsukayama D, Gustilo RB (1991) Effect of time of onset and depth of infection on the outcome of total knee arthroplasty infections. Clin Orthop Relat Res, 273, 98-104.

18. Rodríguez D, Pigrau C, Euba G, Cobo J, García-Lechuz J, Palomino J, Riera M, Del Toro MD, Granados A, Ariza X, 
Ariza X, REIPI Group (Spanish Network for Research in Infectious Disease (2010) Acute haematogenous prosthetic joint infection: prospective evaluation of medical and surgical management. Clin Microbiol Infect, 16(12), 1789-1795.

19. Theis JC, Gambhir S, White J (2007) Factors affecting implant retention in infected joint replacements. ANZ J Surg, 77(10), 877-879.

20. Tintle SM, Forsberg JA, Potter BK, Islinger RB, Andersen RC (2009) Prosthesis retention, serial debridement, and antibiotic bead use for the treatment of infection following total joint arthroplasty. Orthopedics, 32(2), 87.

21. Vilchez F, Martínez-Pastor JC, García-Ramiro S, Bori G, Tornero E, García E, Mensa J, Soriano A (2011) Efficacy of debridement in hematogenous and early post-surgical prosthetic joint infections. Int J Artif Organs, 34(9), 863-869.

22. Azzam KA, Seeley M, Ghanem E, Austin MS, Purtill JJ, Parvizi J (2010) Irrigation and debridement in the management of prosthetic joint infection: traditional indications revisited. J Arthroplasty, 25(7), 1022-1027.

23. Deirmengian C, Greenbaum J, Stern J, Braffman M, Lotke PA, Booth RE Jr, Lonner JH (2003) Open debridement of acute gram-positive infections after total knee arthroplasty. Clin Orthop Relat Res, 416, 129-134.

24. Tornero E, García-Oltra E, García-Ramiro S, Martínez-Pastor JC, Bosch J, Climent C, Morata L, Camacho P, Mensa J, Soriano A (2012) Prosthetic joint infections due to Staphylococcus aureus and coagulase-negative staphylococci. Int J Artif Organs, 35(10), 884-892.

25. Cobo J, Miguel LG, Euba G, Rodríguez D, García-Lechuz JM, Riera M, Falgueras L, Palomino J, Benito N, del Toro MD, Pigrau C, Ariza J (2011) Early prosthetic joint infection: outcomes with debridement and implant retention followed by antibiotic therapy. Clin Microbiol Infect, 17(11), 1632-1637.

26. Bradbury T, Fehring TK, Taunton M, Hanssen A, Azzam K, Parvizi J, Odum SM (2009) The fate of acute methicillinresistant Staphylococcus aureus periprosthetic knee infections treated by open debridement and retention of components. J Arthroplasty, 24(6 Suppl), 101-104.

27. Ferry T, Uçkay I, Vaudaux P, François P, Schrenzel J, Harbarth S, Laurent F, Bernard L, Vandenesch F, Etienne J, Hoffmeyer P, Lew D (2010) Risk factors for treatment failure in orthopedic device-related methicillin-resistant Staphylococcus aureus infection. Eur J Clin Microbiol Infect Dis, 29(2), 171-180.

28. Lora-Tamayo J, Murillo O, Iribarren JA, Soriano A, Sánchez-Somolinos M, et al. (2013) A large multicenter study of methicillin-susceptible and methicillin-resistant Staphylococcus aureus prosthetic joint infections managed with implant retention. Clin Infect Dis, 56(2), 182-194.

29. Triantafyllopoulos GK, Poultsides LA, Zhang W, Sculco PK, Ma Y, Sculco TP (2014) Periprosthetic knee infections treated with irrigation and debridement: outcomes and preoperative predictive factors, J Arthroplasty, 30(4), 649-657.

30. Hsieh PH, Lee MS, Hsu KY, Chang YH, Shih HN, Ueng SW (2009) Gram-negative prosthetic joint infections: risk factors and outcome of treatment. Clin Infect Dis, 49(7), 1036-1043.

31. Martínez-Pastor JC, Muñoz-Mahamud E, Vilchez F, García-Ramiro S, Bori G, Sierra J, Martínez JA, Font L, Mensa J, Soriano A (2009) Outcome of acute prosthetic joint infections due to gram-negative bacilli treated with open debridement and retention of the prosthesis. Antimicrob Agents Chemother, 53(11), 4772-4777.
32. Zürcher-Pfund L, Uçkay I, Legout L, Gamulin A, Vaudaux P, Peter R (2013) Pathogen-driven decision for implant retention in the management of infected total knee prostheses.Int Orthop, 37(8), 1471-1475.

33. Koyonos L, Zmistowski B, Della Valle CJ, Parvizi J (2011) Infection control rate of irrigation and debridement for periprosthetic joint infection. Clin Orthop Relat Res, 469(11), 3043-3048.

34. Choi HR, von Knoch F, Zurakowski D, Nelson SB, Malchau H (2011) Can implant retention be recommended for treatment of infected total knee arthroplasty? Clin Orthop Relat Res, 469(4), 961-969.

35. Schwechter EM, Folk D, Varshney AK, et al. (2011) Optimal irrigation and debridement of infected joint implants: an in vitro methicillin-resistant Staphylococcus aureus biofilm model. J Arthroplasty, 26(Suppl), 109-113.

36. Royo A, Bertrand ML, Ramos L, Fernandez-Gordillo F, Guerado E (2013) Is there still a place for continuous closed irrigation in the management of periprosthetic total knee infection? Open Orthop J, 14(7), 205-210.

37. Martel-Laferrière V, Laflamme $P$, Ghannoum M, Fernandes J, Di Iorio D, Lavergne V (2013) Treatment of prosthetic joint infections: validation of a surgical algorithm and proposal of a simplified alternative. J Arthroplasty, 28(3), 395-400.

38. Buller LT, Sabry FY, Easton RW, Klika AK, Barsoum WK (2012) The preoperative prediction of success following irrigation and debridement with polyethylene exchange for hip and knee prosthetic joint infections. J Arthroplasty, 27(6), 857-64. e1-4.

39. Vilchez F, Martínez-Pastor JC, García-Ramiro S, Bori G, Maculé F, Sierra J, Font L, Mensa J, Soriano A (2011) Outcome and predictors of treatment failure in early post-surgical prosthetic joint infections due to Staphylococcus aureus treated with debridement. Clin Microbiol Infect, 17(3), 439-444.

40. Dixon P, Parish EN, Cross MJ (2004) Arthroscopic debridement in the treatment of the infected total knee replacement. J Bone Joint Surg Br, 86(1), 39-42.

41. Ilahi OA, Al-Habbal GA, Bocell JR, Tullos HS, Huo MH (2005) Arthroscopic debridement of acute periprosthetic septic arthritis of the knee. Arthroscopy, 21(3), 303-306.

42. Waldman BJ, Hostin E, Mont MA, Hungerford DS (2000) Infected total knee arthroplasty treated by arthroscopic irrigation and debridement. J Arthroplasty, 15(4), 430-436.

43. Liu CW, Kuo CL, Chuang SY, Chang JH, Wu CC, Tsai TY, Lin LC (2013) Results of infected total knee arthroplasty treated with arthroscopic debridement and continuous antibiotic irrigation system Indian. J Orthop, 47(1), 93-97.

44. Mont MA, Waldman B, Banerjee C, Pacheco IH, Hungerford DS (1997) Multiple irrigation, debridement, and retention of components in infected total knee arthroplasty. J Arthroplasty, 12(4), 426-433.

45. Chung JY, Ha CW, Park YB, Song YJ, Yu KS (2014) Arthroscopic debridement for acutely infected prosthetic knee: any role for infection control and prosthesis salvage? Arthroscopy, 30(5), 599-606.

46. Osmon DR, Berbari EF, Berendt AR, Lew D, Zimmerli W, Steckelberg JM, Rao N, Hanssen A, Wilson WR (2013) Diagnosis and management of prosthetic joint infection; clinical practice guidelines by the Infectious Diseases Society of America. Clin Infect Dis, 56(1), e1-e25.

47. Hoad-Reddick DA, Evans CR, Norman P, Stockley I (2005) Is there a role for extended antibiotic therapy in a two-stage 
revision of the infected knee arthroplasty? J Bone Joint Surg $\mathrm{Br}, 87(2), 171-174$.

48. Byren I, Bejon P, Atkins BL, Angus B, Masters S, McLardy-Smith P, Gundle R, Berendt A (2009) One hundred and twelve infected arthroplasties treated with 'DAIR' (debridement, antibiotics and implant retention): antibiotic duration and outcome. J Antimicrob Chemother, 63(6), 1264-1271.

49. Puhto AP, Puhto T, Syrjala H (2012) Short-course antibiotics for prosthetic joint infections treated with prosthesis retention. Clin Microbiol Infect, 18(11), 1143-1148.

50. Bernard L, Legout L, Zürcher-Pfund L, Stern R, Rohner P, Peter R, Assal M, Lew D, Hoffmeyer P, Uçkay I (2010) Six weeks of antibiotic treatment is sufficient following surgery for septic arthroplasty. J Infect, 61(2), 125-132.

51. Moran E, Masters S, Berendt AR, McLardy-Smith P, Byren I, Atkins BL (2007) Guiding empirical antibiotic therapy in orthopaedics: the microbiology of prosthetic joint infection managed by debridement, irrigation and prosthesis retention. $\mathrm{J}$ Infect, 55(1), 1-7.

52. Sherrell JC, Fehring TK, Odum S, Hansen E, Zmistowski B, Dennos A, Kalore N (2011) The Chitranjan Ranawat Award: fate of two-stage reimplantation after failed irrigation and debridement for periprosthetic knee infection. Clin Orthop Relat Res, 469(1), 18-25.

Cite this article as: Qasim SN, Swann A \& Ashford R (2017) The DAIR (debridement, antibiotics and implant retention) procedure for infected total knee replacement - a literature review. SICOT J, 3, 2 